MIDPI

MOL2NET, International Conference Series on Multidisciplinary Sciences

sciforum

http://sciforum.net/conference/mol2net-03

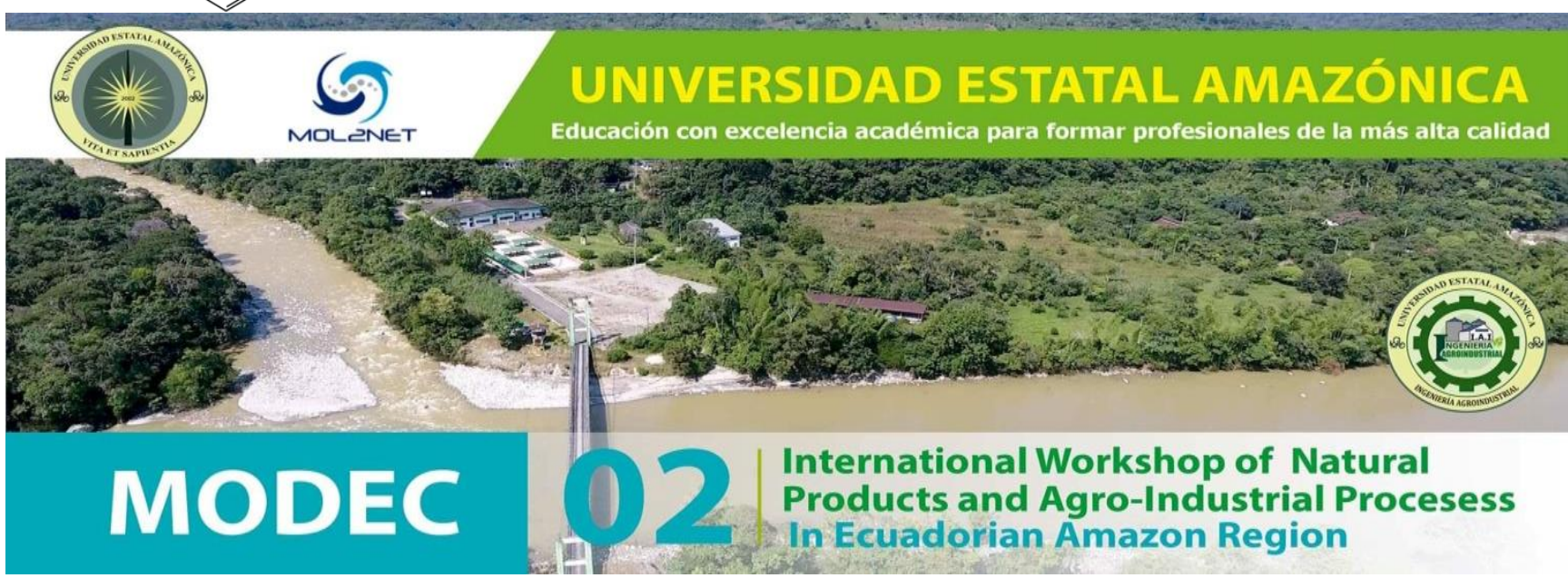

\title{
Relationship between the fed substrates and the physical chemical parameters of an anaerobic biodigester in Ecuadorian Amazon Region.
}

Edwin M. Collahuaso Martínez (E-mail: edwincollahuaso@hotmail.es) ${ }^{a}$, Amaury Perez-Martínez (E-mail: aperezmartinez2009@gmail.com) ${ }^{a}$, Karel Diéguez-Santana (Email: karel.dieguez.santana@gmail.com) ${ }^{a}$, Julio Abel Loureiro-Salabarría (E-mail: julioabelloureiro@gmail.com $)^{\mathrm{b}}$.

${ }^{a}$ Universidad Estatal Amazónica, Paso Lateral km 2 1/2 vía Tena, Puyo, Pastaza, Ecuador

${ }^{b}$ Escuela Superior Politécnica Agropecuaria de Manabí “Manuel Félix López” Carrera de Ingeniería Ambiental, Campus Politécnico Sitio El Limón vía a la Pastora. Calceta, Manabí, Ecuador.

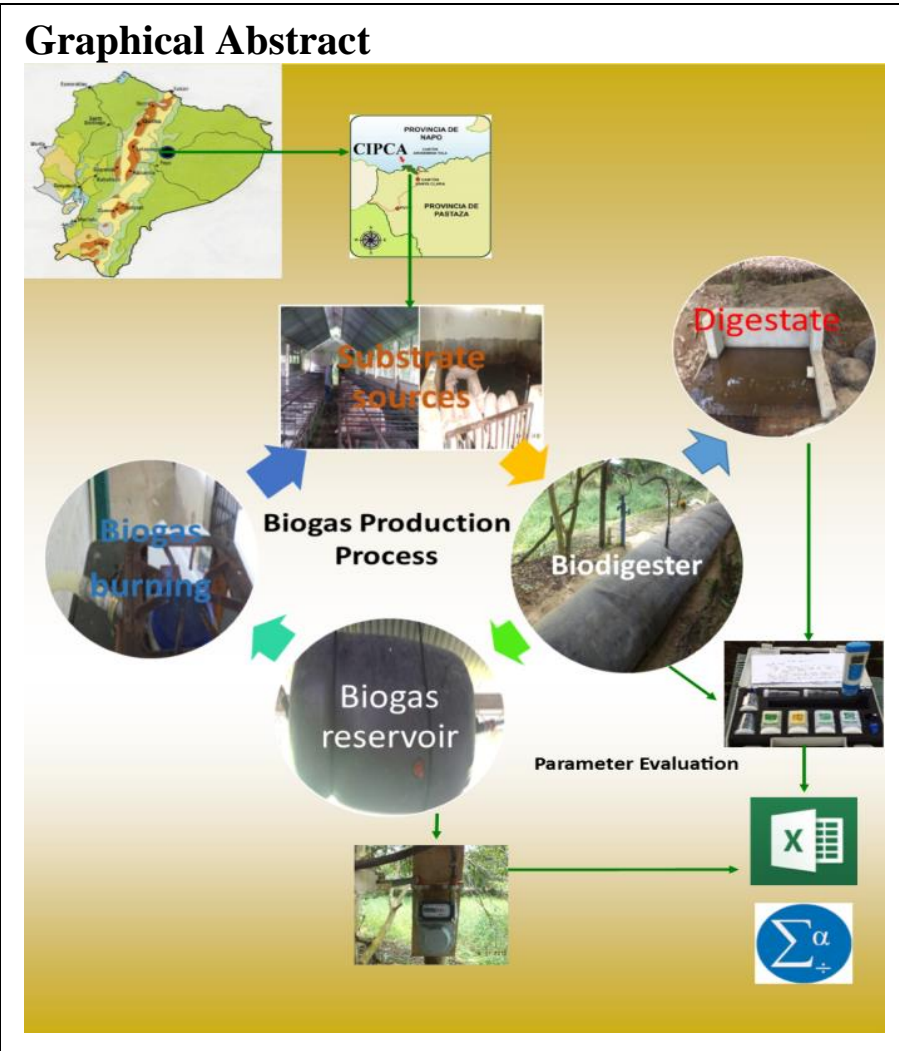

\section{Abstract.}

At present the search for renewable energy sources and raw materials is the attention of many countries that seek to modify their energy and productive matrix. Anaerobic digestion of different substrates is one of the most studied processes. Not only with the aim of generating a renewable energy source but also by the use of waste generated in industry, agriculture and our homes. The operational parameters of this process directly influence the quality of the biogas and digestate that is produced. In addition to influencing the performance of the process. Amazon State University's (UEA) has a bioreactor that is fed mainly with animal manure so that the variability of the raw material quality can influence the product obtained quality. This work aims to relate the influence of the different 
substrates fed on the physical chemical parameter variability ( $\mathrm{pH}$, salinity, conductivity) that affect the digestion process.

Keywords: Anaerobic digestion, animal manure, operational parameters

\section{Acknowledgments}

The authors acknowledge the Catalonia branch of "Ingeniería Sin Fronteras" and the project "Fortalecimiento de la cooperación universitaria/municipal en la implementación de tecnologías apropiadas para el tratamiento y aprovechamiento de residuos orgánicos". They also PhD Jaime Marti and Ing. Janeth Sanchez for cooperation.

\section{References}

1. Cao, J.-P.; Huang, X.; Zhao, X.-Y.; Wei, X.-Y.; Takarada, T. Nitrogen transformation during gasification of livestock compost over transition metal and ca-based catalysts. Fuel 2015, 140, 477-483.

2. $\quad$ Fernandez-Lopez, M.; López-González, D.; Puig-Gamero, M.; Valverde, J.L.; Sanchez-Silva, L. $\mathrm{Co} 2$ gasification of dairy and swine manure: A life cycle assessment approach. Renewable Energy 2016, 95, 552-560.

3. Millner, P.; Ingram, D.; Mulbry, W.; Arikan, O.A. Pathogen reduction in minimally managed composting of bovine manure. Waste Management 2014, 34, 1992-1999.

4. Angelidaki, I.; Ellegaard, L.; Ahring, B.K. Applications of the anaerobic digestion process. Advances in biochemical engineering/biotechnology 2003, 82, 1-33.

5. Zhang, X.; Qiu, W.; Chen, H. Enhancing the hydrolysis and acidification of steam-exploded cornstalks by intermittent ph adjustment with an enriched microbial community. Bioresource technology 2012, 123, 30-35.

6. Sun, Q.; Li, H.; Yan, J.; Liu, L.; Yu, Z.; Yu, X. Selection of appropriate biogas upgrading technology-a review of biogas cleaning, upgrading and utilisation. Renewable and Sustainable Energy Reviews 2015, 51, 521-532.

7. Lamolinara, B.; Perez-Martinez, A.; Dieguez-Santana, K. Digestate quality, problems, processes and feedstocks: A review. In Process 2018.

8. Zhang, Y.; Banks, C.J.; Heaven, S. Co-digestion of source segregated domestic food waste to improve process stability. Bioresource Technology 2012, 114, 168-178.

9. García-Prado, R.; Pérez-Martínez, A.; Diéguez-Santana, K.; Mesa-Garriga, L.; GonzálezHerrera, I.; González-Cortés, M.; González-Suarez, E. Incorporación de otras materias primas como fuentes de azúcares fermentables en destilerías existentes de alcohol. Revista Facultad de Ingeniería Universidad de Antioquia 2015, 75, 130-142.

10. Ward, A.J.; Hobbs, P.J.; Holliman, P.J.; Jones, D.L. Optimisation of the anaerobic digestion of agricultural resources. Bioresource Technology 2008, 99, 7928-7940.

11. El-Mashad, H.M.; Zhang, R. Biogas production from co-digestion of dairy manure and food waste. Bioresource Technology 2010, 101, 4021-4028.

12. Arcos Morales, G.; Palate Checa, B.; Diéguez-Santana, K.; Sablón Cossío, N. Comparación del sistema de producción y ambiental de cuyes en la amazonía y en la sierra ecuatoriana. Revista Caribeña de Ciencias Sociales 2017, (noviembre 2017).

13. Khan, M.A.; Ngo, H.H.; Guo, W.S.; Liu, Y.; Nghiem, L.D.; Hai, F.I.; Deng, L.J.; Wang, J.; Wu, Y. Optimization of process parameters for production of volatile fatty acid, biohydrogen and methane from anaerobic digestion. Bioresource Technology 2016, 219, 738-748.

14. Klocke, M.; Mähnert, P.; Mundt, K.; Souidi, K.; Linke, B. Microbial community analysis of a biogas-producing completely stirred tank reactor fed continuously with fodder beet silage as mono-substrate. Systematic and Applied Microbiology 2007, 30, 139-151.

15. Bouallagui, H.; Touhami, Y.; Ben Cheikh, R.; Hamdi, M. Bioreactor performance in anaerobic digestion of fruit and vegetable wastes. Process Biochemistry 2005, 40, 989-995. 